\title{
Effects of altered TatC proteins on protein secretion efficiency via the twin-arginine translocation pathway of Bacillus subtilis
}

\begin{abstract}
Correspondence
Oscar P. Kuipers

o.p.kuipers@rug.nl
\end{abstract}

Received 3 February 2009

Revised 3 March 2009

Accepted 5 March 2009

\author{
Robyn T. Eijlander, Magdalena A. Kolbusz, Erwin M. Berendsen \\ and Oscar P. Kuipers
}

Department of Molecular Genetics, Groningen Biomolecular Sciences and Biotechnology Institute, University of Groningen, Kerklaan 30, 9751 NN Haren, The Netherlands

\section{INTRODUCTION}

Protein translocation via the twin-arginine translocation (Tat) pathway occurs via a proton gradient-driven process in which pre-folded proteins are transported across the cytoplasmic membrane. This process has been extensively studied and described for the Tat system of plant thylakoids and for the Gram-negative bacterium Escherichia coli (reviewed by Lee et al., 2006; Sargent et al., 2006). In E. coli as well as thylakoids, it has been established that the core complex for Tat-dependent protein translocation consists of the three Tat components TatA, TatB and TatC (Bogsch et al., 1998; Sargent et al., 1998, 1999). The current working model describes recognition of the Tat substrate (via its double argininecontaining signal peptide) by a membrane-bound TatBC complex (Alami et al., 2003). A separate TatA complex is then recruited to form a pore through which translocation can occur (Gohlke et al., 2005; Lange et al., 2007).

Much less is known about the mechanism of Tat substrate recognition, binding and translocation in Gram-positive bacteria. One of the most striking differences in Tat machinery

Two supplementary tables are available with the online version of this paper. composition is the absence of a TatB protein in most Grampositive organisms, with the exception of Streptomyces species. Additionally, some bacteria, including the Gram-positive model organism Bacillus subtilis, contain multiple copies of tatA and tat $C$ on the chromosome. B. subtilis is a nonpathogenic soil-dwelling bacterium known for its ability to secrete high amounts of protein into the extracellular medium. Previous studies have described the presence of three orthologues of tatA (namely tatAd, tatAy and tat $A c$ ) and two orthologues of tatC ( $\operatorname{tat} C d$ and $\operatorname{tat} C y$ ) on the B. subtilis chromosome (Jongbloed et al., 2000). Their protein products form two separate protein translocation complexes, TatAdCd and TatAyCy, which display different substrate specificities. The function of the third TatA protein, TatAc, is unknown, although it has been established that it plays no part in the secretion of the known Tat-dependent substrates (Jongbloed et al., 2004; Eijlander et al., 2009). Recently, a working model has been proposed for B. subtilis, in which the TatA protein has a dual function, as it can complement for the absence of both TatA and TatB in E. coli (Barnett et al., 2008). The different substrate specificities observed within B. subtilis still apply when the two Tat translocases are heterologously expressed in E. coli, because the TatAyCy complex is unable to secrete the E. coli Tat substrate TorA, in contrast to the TatAdCd complex (Barnett et al., 2008). 
TatC is the largest Tat component, containing six membrane-spanning domains (Behrendt et al., 2004; Punginelli et al., 2007). Together with TatB, it forms the initial substrate-binding site in E. coli. Site-directed mutagenesis studies on the TatC protein have pointed to a range of essential residues in the cytoplasmic $\mathrm{N}$ terminus as well as the first cytoplasmic loop (Allen et al., 2002; Buchanan et al., 2002) and have eventually led to the conclusion that the complete $\mathrm{N}$-terminal half of TatC is involved in the binding of Tat-dependent substrates (Holzapfel et al., 2007). In this study, the results from these mutagenesis experiments were used as a reference to identify essential residues in the TatC proteins of B. subtilis. Various chimeric TatC proteins consisting of complementary regions of TatCd and TatCy, as well as variants of TatCd and TatCy with single alanine substitutions, were constructed to assess the determinants of Tat-dependent protein translocation in B. subtilis. Using translocation assays we have determined essential residues for the secretion of both YwbN and $\mathrm{PhoD}$ and we point out significant differences in the degree of their importance not only when compared to earlier findings for E. coli TatC, but also between the two TatC components of $B$. subtilis itself.

\section{METHODS}

Bacterial strains, plasmids and media. All strains and plasmids used in this study are listed in Table 1 . All strains were grown in TY (tryptone/yeast extract) medium, consisting of Bacto tryptone (1\%, w/v), Bacto yeast extract $(0.5 \%, \mathrm{w} / \mathrm{v})$ and $\mathrm{NaCl}(1 \%, \mathrm{w} / \mathrm{v})$. When appropriate, media were supplemented with erythromycin (Em; $5 \mu \mathrm{g}$ $\left.\mathrm{ml}^{-1}\right)$, kanamycin $\left(\mathrm{Km} ; 10 \mu \mathrm{g} \mathrm{ml}^{-1}\right)$, chloramphenicol $(\mathrm{Cm} ; 5 \mu \mathrm{g}$ $\mathrm{ml}^{-1}$ ) and/or spectinomycin (Sp; $100 \mu \mathrm{g} \mathrm{ml}^{-1}$ ). To ensure the production of YwbN-myc and $\mathrm{PhoD}$, the expression of the corresponding genes was induced by the addition of $1 \%$ xylose after the cultures entered the exponential growth phase.

DNA cloning techniques. All cloning techniques and transformation of E. coli were performed as described by Sambrook et al. (1989). Transformation of B. subtilis was performed as described by Bron \& Venema (1972). All enzymes were from Roche Molecular Biochemicals or Fermentas Life Sciences. PCR was performed using Phusion DNA polymerase (Finnzymes) as described by van Dijl et al. (1995). All primers used are listed in Supplementary Table S1, available with the online version of this paper.

Construction of TatC hybrid proteins. The topology of B. subtilis TatCy and TatCd was predicted using TMHMM Server v. 2.0 (http:// www.cbs.dtu.dk/services/TMHMM-2.0/) and used for the construction of the TatCd/TatCy hybrid proteins, allowing a direct replacement of specific cytoplasmic loops or transmembrane segments of TatCy by corresponding loops and transmembrane segments of TatCd. The predicted topologies of the resulting hybrids are depicted in Fig. 1(a).

To construct plasmid pHBtatCy the tat $C y$ gene was amplified from $B$. subtilis 168 chromosomal DNA using primers MKCy-F and MKCysR. The amplified fragment was cleaved with SacI and BamHI and cloned into the corresponding sites of pHB201 (Bron et al., 1998). Plasmid $\mathrm{pHBtatCd}$ was constructed in a similar manner using primers MKCd-F and MKCds-R. For the construction of plasmid pHBtatC$\mathrm{H} 1$ the $5^{\prime}$ half of tatCd and the $3^{\prime}$ half of tat $C y$ were fused together using overhang PCR. In short, the $5^{\prime}$ half of tat $C d$ was amplified using primers MKCd-F and MKCd5-R. The 3' half of tatCy was amplified using primers MKCy3-F and MKCys-R. The amplified fragments were diluted $1: 100$ and used in a second PCR, in which they were able to function as primers on each other. The outward primers

Table 1. Plasmids and strains

\begin{tabular}{|c|c|c|}
\hline Strain or plasmid & Relevant properties & Reference \\
\hline \multicolumn{3}{|l|}{ Plasmids } \\
\hline pHB201 & B. subtilis/E. coli shuttle vector with P59 constitutive promoter; $6.6 \mathrm{~kb} ; \mathrm{Cm}^{\mathrm{r}} \mathrm{Em}^{\mathrm{r}}$ & Bron et al. (1998) \\
\hline pHBtatCd & pHB201 derivative containing B. subtilis tatCd; $7.3 \mathrm{~kb} ; \mathrm{Cm}^{\mathrm{r}} \mathrm{Em}^{\mathrm{r}}$ & This study \\
\hline pHBtatC-H1 & pHB201 derivative containing B. subtilis tatC hybrid $1 ; 7.3 \mathrm{~kb} ; \mathrm{Cm}^{\mathrm{r}} \mathrm{Em}^{\mathrm{r}}$ & This study \\
\hline pHBtatC-H2 & pHB201 derivative containing B. subtilis tatC hybrid $2 ; 7.3 \mathrm{~kb} ; \mathrm{Cm}^{\mathrm{r}} \mathrm{Em}^{\mathrm{r}}$ & This study \\
\hline pHBtatC-H4 & pHB201 derivative containing B. subtilis tatC hybrid $4 ; 7.3 \mathrm{~kb} ; \mathrm{Cm}^{\mathrm{r}} \mathrm{Em}^{\mathrm{r}}$ & This study \\
\hline pHBtatC-H5 & pHB201 derivative containing B. subtilis tatC hybrid $5 ; 7.3 \mathrm{~kb} ; \mathrm{Cm}^{\mathrm{r}} \mathrm{Em}^{\mathrm{r}}$ & This study \\
\hline pAX01 & Integrates into the B. subtilis lacA locus; $7.7 \mathrm{~kb} ; \mathrm{Ap}^{\mathrm{r}} \mathrm{Em}^{\mathrm{r}}$ & Härtl et al. (2001) \\
\hline pAXphoD & pAX01 derivative with $p h o D$ behind the $\mathrm{P}_{x y l A}$ promoter; $9.4 \mathrm{~kb} ; \mathrm{Ap}^{\mathrm{r}} \mathrm{Em}^{\mathrm{r}}$ & This study \\
\hline $\mathrm{pJCd} 2$ & pUC21 derivative for the disruption of tatCd; $6.3 \mathrm{~kb} ; \mathrm{Ap}^{\mathrm{r}} \mathrm{Km}^{\mathrm{r}}$ & Jongbloed et al. (2000) \\
\hline \multicolumn{3}{|c|}{$\cos ^{2}$} \\
\hline $168 \mathrm{X}-y w b N$ & $\operatorname{trpC2}$ amyE::xylA-ywbN-myc; $\mathrm{Cm}^{\mathrm{r}}$ & Jongbloed et al. (2004) \\
\hline $168 \Delta t a t C d C y \mathrm{X}-y w b N$ & 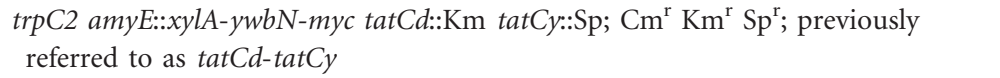 & Jongbloed et al. (2004) \\
\hline $168 \mathrm{X}-\mathrm{phoD}$ & $\operatorname{trpC2}$ lacA::xylA-phoD; $\mathrm{Em}^{\mathrm{r}}$ & This study \\
\hline $168 \Delta$ tatCd X-phoD & $\operatorname{trpC2}$ lacA::xylA-phoD tatCd::Km; $\mathrm{Em}^{\mathrm{r}} \mathrm{Km}^{\mathrm{r}}$ & This study \\
\hline
\end{tabular}


(a)

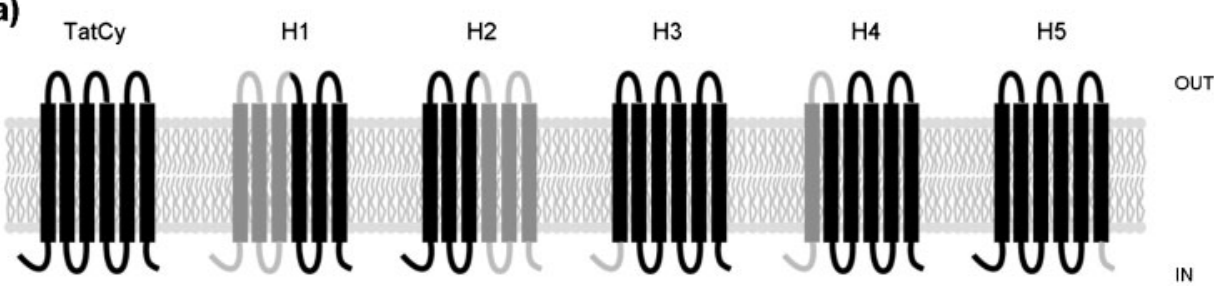

(b)

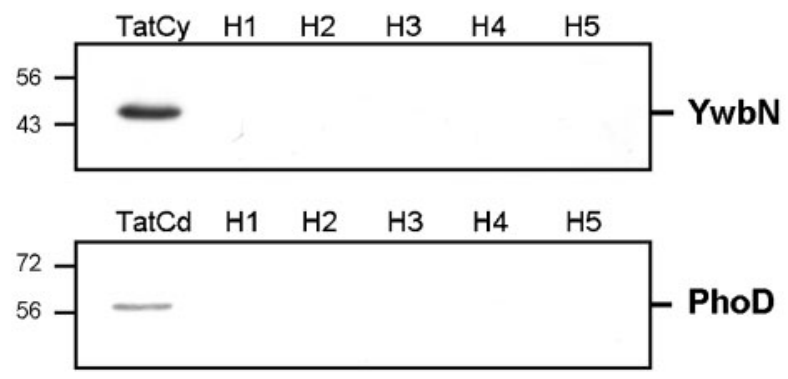

(c)

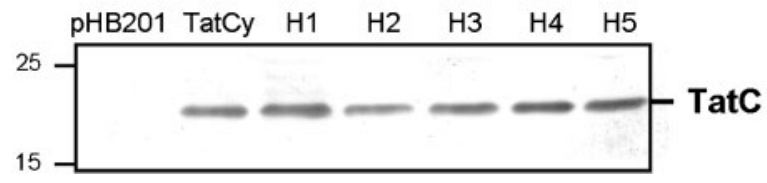

Fig. 1. Secretion activity of TatC hybrid proteins. (a) The cytoplasmic, transmembrane and extracellular regions in TatCy (black) and TatCd (grey) were predicted using TMHMM server v. 2.0 and used to construct five different TatC hybrid proteins as detailed in Methods. (b) Secretion of YwbN (top panel) and PhoD (lower panel) by TatCd/Cy chimeric proteins. Samples were prepared and analysed by SDS-PAGE and immunoblotting as described in Methods. The secretion of YwbN or PhoD to the extracellular medium by plasmid-borne TatCy (lane TatCy), TatCd (lane TatCd) and the TatC hybrids (lanes H1 to H5) was detected with specific antibodies against the myc-epitope on $\mathrm{YwbN}$ or against PhoD, respectively. The molecular mass (in kDa) is indicated on the left. (c) Detection of TatCd/Cy hybrid proteins in the membrane. Membranes were isolated and samples were prepared and analysed by SDS-PAGE and immunoblotting as detailed in Methods. Equal amounts of membrane fraction were loaded on the gel. TatCy and the TatC hybrid proteins $(\mathrm{H} 1-\mathrm{H} 5)$ were detected with specific anti-TatCd antibodies.

MKCd-F and MKCys-R were included in the reaction to ensure amplification of the fused product. The final product was cleaved with SacI and BamHI and cloned into the corresponding sites of pHB201. The additional TatC hybrids were constructed in a similar manner. The correct DNA sequence of all constructs was verified by DNA sequencing (ServiceXS).

Construction of TatC variants. The amino acid sequences of Tat components of B. subtilis and E. coli as deduced from the SubtiList and Colibri Databases were used for comparisons using the EMBLEBI ClustalW2 alignment tool. Based on the protein sequence alignment and previous mutagenesis studies performed for E. coli TatC, conserved and non-conserved residues in TatCy and TatCd were selected for alanine substitutions. Amino acids were replaced by alanines using Phusion Site-Directed Mutagenesis according to the manufacturer's (Finnzymes) instructions. For TatCy and TatCd point mutations $0.6 \mathrm{ng} \mu^{-1}$ of plasmid pHBtatCy or plasmid pHBtatCd respectively was used as template DNA. PCR products were cleaved with $D p n I$ directly after amplification to remove all template DNA before ligation with T4 ligase and transformation into E. coli. The constructs obtained were sequenced (ServiceXS) to ensure correct amino acid substitutions.
Construction of $B$. subtilis 168 X-phoD and $168 \Delta$ tatCd XphoD. For xylose-inducible phoD ectopically integrated into the chromosome, phoD was amplified using JJPhoD01 and JJPhoD04 primers. The amplified fragment was cleaved with $\mathrm{XbaI}$ and $\mathrm{BamHI}$ and cloned into SpeI- and BamHI-digested pAX01 (Härtl et al., 2001). The resulting plasmid, pAXphoD, was used to transform B. subtilis 168 and allowed to integrate into the lacA locus to create B. subtilis strain $168 \mathrm{X}$-phoD. Production and secretion of PhoD was verified after growth in the presence of xylose. Additionally, the tat $C d$ gene was disrupted as previously described by Jongbloed et al. (2000) to create B. subtilis strain $168 \Delta$ tatCd X-phoD.

Protein techniques. To detect YwbN-myc and PhoD, medium and cellular fractions were prepared as described previously (Jongbloed et al., 2000). After separation by SDS-PAGE, proteins were transferred to a PVDF membrane (Molecular Probes) as described by Towbin et al. (1979). YwbN-myc and PhoD were visualized as described previously (Eijlander et al., 2009).

To detect TatC proteins in the membrane, overnight cultures were diluted to an $\mathrm{OD}_{600}$ of 0.1 in fresh TY broth supplemented with antibiotics. Cells were grown to late exponential phase and harvested 
by centrifugation. Next, the cell pellet was incubated in Bacillus Birnboim A buffer (20\% sucrose, $10 \mathrm{mM}$ Tris/ $\mathrm{HCl} \mathrm{pH} 8.1,10 \mathrm{mM}$ EDTA, $50 \mathrm{mM} \mathrm{NaCl}$ ) with $2 \mathrm{mg}$ lysozyme $\mathrm{ml}^{-1}$ for $1 \mathrm{~h}$ at $37^{\circ} \mathrm{C}$. The cells were further disrupted by sonication. Membranes were separated from the cytoplasm by ultracentrifugation at 70000 r.p.m. at $4{ }^{\circ} \mathrm{C}$ for 30 min (Beckman Optima TLX ultracentrifuge). The membrane pellet was resuspended in solubilization buffer $(30 \mathrm{mM}$ Tris/ $\mathrm{HCl} \mathrm{pH} \mathrm{8.0,}$ $10 \%$ glycerol, $50 \mathrm{mM} \mathrm{NaCl}, 1 \%$ Triton-X-100) on a rotor at $4{ }^{\circ} \mathrm{C}$ overnight. Insoluble material was removed by ultracentrifugation, after which the supernatant was collected and labelled as membrane fraction. SDS-PAGE samples of membrane fractions were prepared as described by Laemmli (1970) and analysed by SDS-PAGE and Western blotting using antibodies against B. subtilis TatCd (kindly provided by J. Müller, University of Jena, Germany) and horseradish peroxidase-conjugated donkey anti-rabbit antibodies (Amersham Biosciences) according to the manufacturer's instructions.

\section{RESULTS}

\section{TatC hybrid proteins are unable to secrete $\mathrm{YwbN}$}

To determine which part(s) of the B. subtilis TatCd and TatCy proteins are involved in substrate translocation activity, TatC hybrid proteins were constructed as described in Methods. The E. coli TatC protein has an experimentally proven topology of six transmembrane regions, with an in-in topology (Behrendt et al., 2004; Punginelli et al., 2007). For this study, the topologies of $B$. subtilis TatCd and TatCy were predicted and compared to the known topology of E. coli TatC. These models were used to determine suitable fusion sites between TatCy and TatCd regions. The predicted topologies of the TatC hybrids constructed are depicted in Fig. 1(a).

The hybrid tat $C$ genes were expressed from the pHB201 vector containing the constitutive P59 promoter, which is derived from Lactococcus lactis subsp. cremoris Wg2 and functions as a strong promoter in B. subtilis (van der Vossen et al., 1987). The ability of the TatC hybrids to secrete the TatAyCy-dependent substrate YwbN was tested in a B. subtilis $\Delta$ tat $C d C y$ mutant background. Cells were grown and SDS-PAGE samples were prepared as described in Methods and analysed by immunoblotting. Surprisingly, none of the constructed hybrids was able to complement the absence of TatCy in the $\Delta t a t C d C y$ mutant strain (Fig. 1b, top panel). As a positive control, wild-type TatCy was used, which can restore secretion of YwbN in this mutant background (Fig. 1b, top panel, lane TatCy).

\section{TatC hybrid proteins are unable to secrete PhoD}

The only TatAdCd-dependent substrate identified to date is the phosphodiesterase PhoD. Its gene is located upstream of the tatAd and tatCd genes in the same operon, which is controlled by the PhoP-dependent $\mathrm{P}_{\text {phoD }}$ promoter. Consequently, this operon is only expressed during growth in a low-phosphate medium, inducing the so-called pho response (Eder et al., 1999; Punginelli et al., 2007). To bypass growth in a low-phosphate medium, we made use of a $B$. subtilis strain with a xylose-inducible phoD gene integrated ectopically into the lacA locus. Expression of $p h o D$ in this strain after induction with xylose in a rich medium results in the expression of endogenous tatAd and tat $C d$, suggesting an additional regulatory role of PhoD ( R. T. Eijlander and others, unpublished). The mechanism of this regulatory role and possible other factors involved are not yet known and are currently under investigation. For this study, tat $C d$ was disrupted by a kanamycin-resistance cassette as previously described (Jongbloed et al., 2000), resulting in the complete abolition of PhoD secretion (data not shown).

We investigated the ability of the TatC hybrid proteins to secrete PhoD. In accordance with the observations described above for YwbN secretion in a $\Delta t a t C d C y$ background, TatC complementation by the hybrid proteins in a $\Delta t a t C d$ mutant strain with xylose-inducible $p h o D$ did not restore secretion of PhoD (Fig. 1b, lower panel), whereas complementation by wild type TatCd did (Fig. 1b, lower panel, lane TatCd).

To ensure proper production and integration of the hybrid TatC proteins into the membrane, membranes were isolated and solubilized as detailed in Methods, and immunoblotted with specific antibodies raised against the TatCd protein of B. subtilis. Conveniently, these antibodies cross-react with $\mathrm{TatCy}$, allowing detection of both proteins. As can be seen in Fig. 1(c), all full-length TatC hybrids can be visualized in the membrane fractions, confirming their production and stability. Importantly, no signs of protein degradation were observed.

\section{Site-directed mutagenesis of conserved and non- conserved residues of TatCy and TatCd into alanines}

Previous mutagenesis studies on E. coli TatC have already identified a range of essential or important conserved residues (Allen et al., 2002; Buchanan et al., 2002; Kreutzenbeck et al., 2007; Strauch \& Georgiou, 2007; Holzapfel et al., 2007), whose modification led to severe effects on or a complete abolition of Tat-dependent protein secretion. Such mutations can lead to an inability of the protein to recognize or bind the substrate (Holzapfel et al., 2007; McDevitt et al., 2006), to actively translocate the substrate, or to form a stable complex with additional essential TatA, B or C units (Barrett et al., 2005). An overview of the changed residues in E. coli TatC and the effects on substrate translocation is shown in Supplementary Table S2. An important outcome of such studies is the identification of the TatC $\mathrm{N}$-terminal region as the signal peptide recognition and binding site (Holzapfel et al., 2007).

Based on TatC, TatCd and TatCy protein sequence alignments and previous mutagenesis studies involving $E$. coli TatC, several conserved and non-conserved residues in the $\mathrm{N}$-terminal regions of TatCy and TatCd were selected for single alanine substitutions. In addition, two C- 
terminal deletions of TatCy of variable lengths were included in this study ( -5 and -8$)$. An outline of the TatCy and TatCd site-directed mutants is depicted in Fig. 2(a). The ability of these altered TatC proteins to secrete YwbN or PhoD is shown in Fig. 2(b) and summarized in Supplementary Table S2. Of the eleven TatCy variants, four (H14A, L18A, K20A and L98A) were found to be completely defective in YwbN secretion and one (E102A) severely affected (Fig. 2b, top panel). Interestingly, a significantly larger number of TatCd variants was impaired in PhoD secretion, as only the K3A, R17A and M102A variants were still active (Fig. 2b, lower panel), with $\operatorname{TatCd}_{\mathrm{K} 3 \mathrm{~A}}$ as well as $\mathrm{TatCd}_{\mathrm{R} 17 \mathrm{~A}}$ showing less efficient secretion of PhoD. Although the TatCy $\mathrm{F}_{\mathrm{R} 19 \mathrm{~A}}$ variant also seems to show a decreased efficiency in YwbN secretion, this effect was not always observed during replicate experiments: $\mathrm{TatCy}_{\mathrm{R} 19 \mathrm{~A}}$ typically restores $\mathrm{YwbN}$ secretion comparable to wild type levels (data not shown). The $\mathrm{TatC}_{\mathrm{E} 102 \mathrm{~A}}$ variant, however, is typically severely affected in YwbN secretion efficiency.

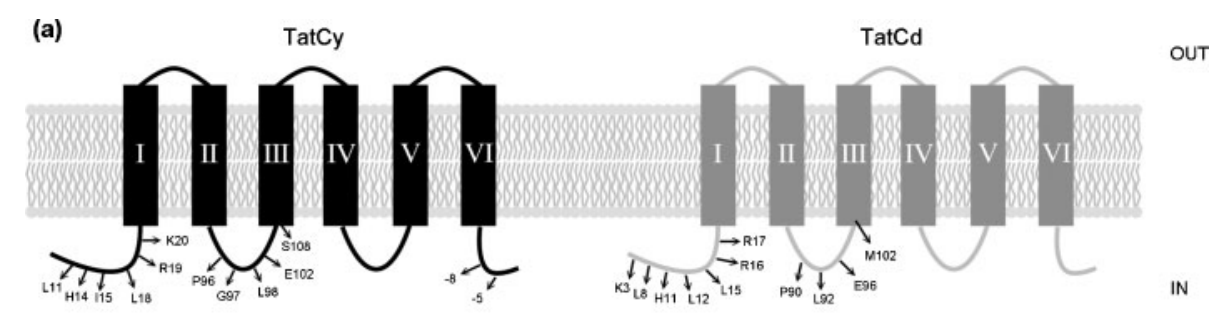

(b)
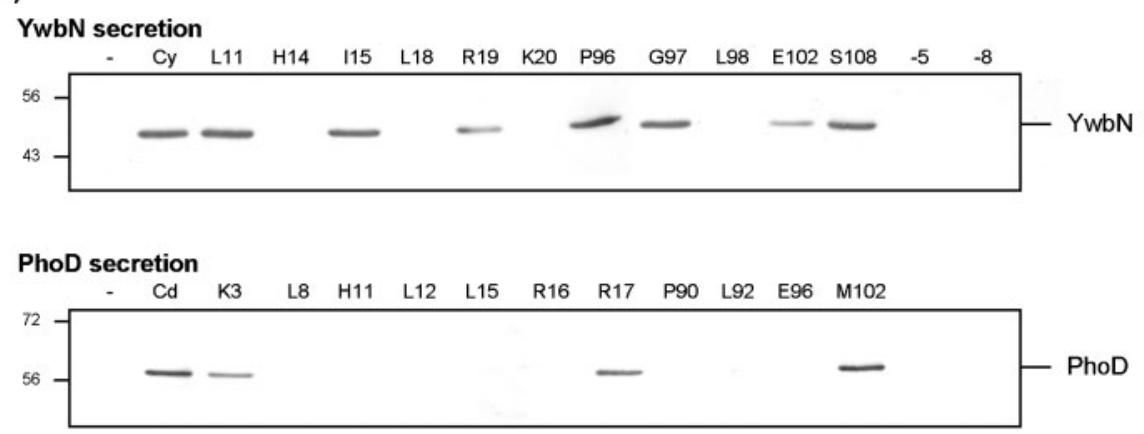

(c)

TatCy sd mutants

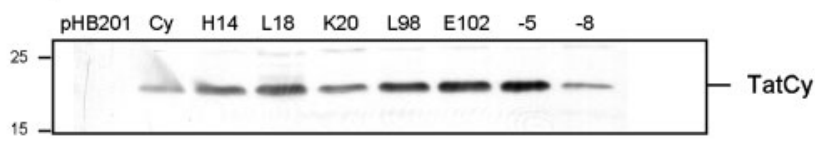

TatCd sd mutants

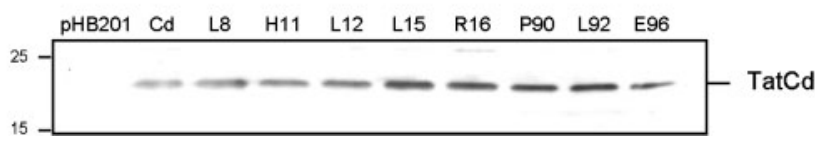

Fig. 2. Protein secretion activity by several TatCy and TatCd variants. (a) Schematic representation of TatCy (black) and TatCd (grey) altered proteins. The transmembrane segments are indicated in roman numerals. The positions of the residues changed into alanines in this study are indicated. The two C-terminal deletions of TatCy are indicated: -5 (five amino acid deletion) and -8 (eight amino acid deletion). (b) Secretion of YwbN (top panel) and PhoD (lower panel) by altered TatCy and TatCd proteins. Samples were prepared and analysed by SDS-PAGE and immunoblotting as described in Methods. The positions of molecular mass markers (in $\mathrm{kDa}$ ) are indicated on the left. The negative control, consisting of the empty pHB201 vector, is indicated by As a positive control, tatCy or tatCd expressed from pHB201 was used (Cy and Cd, respectively). The TatCy variants as depicted in (a) are indicated by a letter and number. (c) Detection of TatCy (top panel) and TatCd (lower panel) variant proteins in the membrane, performed as described in the legend of Fig. 1(c). TatCy and TatCd were visualized using antibodies against TatCd. The positions of molecular mass markers (in $\mathrm{kDa}$ ) are indicated on the left. Negative control, plasmid pHB201 (pHB201); positive control, TatCy (Cy) or TatCd (Cd). The letters and numbers (e.g. H14) indicate the amino acid in TatCy or TatCd that was replaced by an alanine. 
Non-conserved residues were modified to study their role in the substrate specificity of TatCd and TatCy. The first cytoplasmic loop of TatCy and TatCd contains the highly conserved region ERKVTLxYIP (Fig. 3a). The x represents the position of a unique residue for each protein, namely a serine for TatCy (S108) and a methionine for TatCd (M102). The side chains of these residues display very different properties, but apparently have no effect on substrate specificity, as substitution to alanines did not affect secretion for either protein (Fig. 2b).

The extreme $\mathrm{C}$ terminus of TatCy is extended by five amino acids when compared to that of TatCd (Fig. 3a). The importance of these extended residues was investigated by complementing a $\Delta$ tatCdCy mutant strain with two Cterminal deletion variants of TatCy. The five amino acid deletion variant as well as the eight amino acid deletion variant were unable to complement for the absence of wild type TatCy in the secretion of YwbN (Fig. 2b, top panel, lanes -5 and -8 ). This implies an important, if not essential, role of the TatCy $\mathrm{C}$ terminus in substrate translocation.

Finally, to ensure production and integration of the inactive TatC variant proteins into the membrane, their presence was detected in the membrane as described above (Fig. 2c).

\section{DISCUSSION}

The Gram-positive bacterium B. subtilis contains two independent Tat translocases, TatAdCd and TatAyCy, each responsible for the secretion of one specific substrate, PhoD and YwbN, respectively. Complementation studies in $E$. coli $\Delta t a t A / E$ and $\Delta t a t B$ mutants have shown that the

\section{(a) Protein sequence alignment of TatCy, TatCd and E. coli TatC}

\begin{tabular}{|c|c|c|}
\hline TatCy & MTRMKVNQMSLLEHIAELRKRLLIVALAFVVFF IAGFFLAKPI IVYLQETDEAKQ- - - LT & 57 \\
\hline Tatcd & - - -MDKKETHLIGHLEELRRRI IVTLAAFFLFLITAFLFVQDIYDWLIRDLDGKL- - -AV & 54 \\
\hline \multirow[t]{2}{*}{ TatC } & - -MSVEDTQPLITHLIELRKRLLNCI IAVIVIFLCLVYFANDIYHLVSAPLIKQLPQGST & 58 \\
\hline & 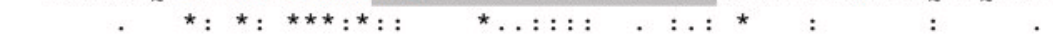 & \\
\hline Tatcy & LNAFNLTDPLYVFMQFAFI IGIVLTSPVILYQLWAFVSPGLYEKERKVTLSYIPVSILLF & 117 \\
\hline Tatcd & LGP- - -SEILWVYMMLSGICA IAAS I PVAAYQLWRFVAPALTKTERKVTLMYIPGLFALF & 111 \\
\hline \multirow[t]{2}{*}{ TatC } & MIATDVASPFFTPIKLTFMVSLILSAPVILYQVWAF IAPALYKHERRLVVPLLVSSSLLF & 118 \\
\hline & 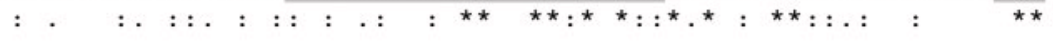 & \\
\hline TatCy & LAGLSFSYYILFPFVVDFMKR I SQDLNVNQVIGINEYFHFLLQLT I PFGLLFQMPVI LMF & 177 \\
\hline Tatcd & LAGISFGYFVLFPIVLSFLTHLSSG-HFETMFTADRYFRFMVNLSLPFGFLFEMPLVVMF & 170 \\
\hline \multirow[t]{2}{*}{ TatC } & YIGMAFAYFVVFPLAFGFLANTAPE-GVQVSTDIASYLSFVMALFMAFGVSFEVPVAIVL & 177 \\
\hline & 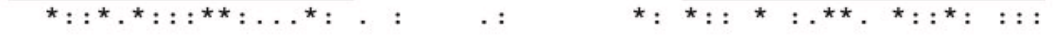 & \\
\hline Tatcy & LTRLGIVTPMFLAKIRKYAYFTLLVIAALITPPELLSHMMVTVPLLILYEISILISKAAY & 237 \\
\hline Tatcd & LTRLGILNPYRLAKARKLSYFLLIVVS ILITPPDFISDFLVMI PLLVLFEVSVTLSAFVY & 230 \\
\hline \multirow[t]{2}{*}{ TatC } & LCWMGITSPEDLRKKRPYVLVGAFVVGMLLTPPDVFSQTLLAI PMYCLFEIGVFFSRFYV & 237 \\
\hline & 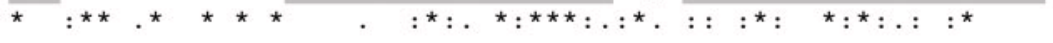 & \\
\hline TatCy & RKAQKSSAADRDVSSGQ---- 254 & \\
\hline Tatcd & KKRMREETAAAA- - - - - 242 & \\
\hline TatC & $\begin{array}{l}\text { GKGRNREEENDAEAESEKTEE } 258 \\
\text { * }\end{array}$ & \\
\hline
\end{tabular}

\section{(b) Protein sequence alignment of $\mathbf{N}$ regions of various Tat signal peptides}

$\begin{array}{lr}\text { SufI } & \text { MSLSRRQFIQ } \\ \text { TorA } & \text { MNNNDLFQASRRRF LAQ } \\ \text { YwbN } & \text { MSDEQKKPEQIHRRDILK } \\ \text { PhOD } & \text { MAYDSRFDEVQKLKEESFQNNTFDRRFIQ }\end{array}$

Fig. 3. Protein sequence alignments. (a) Predicted hydrophobic regions in B. subtilis TatCy, TatCd and E. coli TatC are shaded. The effects of amino acid substitution of residues are indicated in colours: red, essential; green, non-essential; blue, important; pink, inconclusive. (b) Alignment of the sequences of the $\mathrm{N}$ region of the signal peptides of $E$. coli substrates Sufl and TorA as well as $B$. subtilis Tat substrates $\mathrm{YwbN}$ and PhoD. The double arginine motif is indicated in bold. The conserved +2 phenylalanine residue is underlined. The divergent isoleucine in this position in the signal peptide of YwbN in highlighted in red and bold. A common feature in all four signal peptides consisting of the presence of hydrophobic residues in positions +3 and -2 is shown in italics. 
TatAd component of B. subtilis is bifunctional and able to restore secretion of the TorA substrate in both mutant backgrounds (Barnett et al., 2008). In addition, our recent findings indicate an ability of TatAd to form an active complex not only with TatCd, but also with TatCy when TatAd is overproduced (Eijlander et al., 2009). The opposite combination, i.e. TatAyTatCd, was not found to be active, leading to the hypothesis that the TatCy component may contain the specificity determinant(s) for recognition and binding of the YwbN substrate. Likewise, previous studies in E. coli and plant thylakoids have identified the TatBC complex as the substrate receptor complex (Cline \& Mori, 2001; Mangels et al., 2005), with the TatC protein interacting specifically with the RRconsensus region in the signal peptide (Gérard \& Cline, 2006; Alami et al., 2003). In this study, we have sought to investigate the importance of specific regions and residues in the two TatC proteins of B. subtilis (TatCy and TatCd) and compare our findings to previously published observations for E. coli TatC.

\section{Inactivity of TatC hybrid proteins points towards multiple essential regions}

Even though the TatC protein is not highly conserved among organisms, certain regions contain a high density of conserved residues, particularly the cytoplasmic loops (Buchanan et al., 2002). With the construction of several TatCd/Cy chimeric proteins, we set out to determine which regions are essential for the secretion of YwbN or PhoD. Unexpectedly, as shown in Fig. 1(b), none of these hybrid proteins was able to secrete either YwbN or PhoD in $\Delta$ tatCy and/or $\Delta$ tatCd mutant backgrounds. This inability is not due to an instability of the chimeric proteins, because Fig. 1(c) shows their presence in the membrane, indicating a stable membrane integration. We conclude that activity determinants for substrate binding, substrate translocation or complex formation with the TatA counterpart in both $B$. subtilis TatC proteins are localized in multiple regions, which are extremely sensitive to modification.

Because all B. subtilis TatC hybrids containing an altered $\mathrm{N}$ or $\mathrm{C}$ terminus were inactive, it is reasonable to assume that not only the $\mathrm{N}$-terminal part (as previously suggested by Allen et al., 2002; Buchanan et al., 2002; Holzapfel et al., 2007), but also the extreme $C$ terminus of TatC is essential in the secretion of Tat substrates (Fig. 1b, lane H5). This is confirmed by the results obtained for two C-terminal deletion mutants of TatCy, which both no longer secrete YwbN (Fig. 2b, upper panel, lanes -5 and -8 ). Importantly, this extended C-terminal region is only present in TatCy (and not in TatCd) and may be particularly important for the substrate translocation activity of the TatCy protein. Whether this part of the protein is involved in substrate binding or substrate translocation, or is perhaps required for correct complex formation with TatAy, was not investigated in this study and will have to be addressed in additional experiments.

\section{Conserved TatC residues show differences in degree of importance for Tat-dependent protein secretion}

Previous mutagenesis studies involving E. coli TatC have provided a wealth of data concerning essential and important residues in the TatC protein for Tat substrate binding and translocation (summarized in Supplementary Table S2). In this study, we have applied similar approaches to obtain clues as to the importance of conserved residues in Gram-positive TatC proteins. Based on protein sequence alignments and results obtained from previous studies in E. coli, a range of conserved and nonconserved residues in the $\mathrm{N}$-terminal regions of $B$. subtilis TatCy and TatCd were selected for substitution by alanines. The effects of these alterations on the secretion of YwbN and PhoD, respectively, are shown in Fig. 2(b).

Strikingly, substitution of conserved residues in TatCy and TatCd resulted in different effects on their respective substrate secretion activity. In addition, significant differences in importance of conserved residues in TatCy, TatCd and E. coli TatC were observed. For instance, the E. coli Tat $_{\mathrm{L} 16 \mathrm{~A}}$ mutant showed only a minor effect on secretion efficiency of TorA or the TorA-GFP fusion protein (Allen et al., 2002), whereas the leucine-alanine substitution in the same position in TatCy $\left(\mathrm{TatCy}_{\mathrm{L} 18 \mathrm{~A}}\right)$ and TatCd $\left(\operatorname{TatCd}_{\mathrm{L15A}}\right)$ resulted in a complete block in transport of YwbN or PhoD, respectively.

The glutamate in position 103 is one of the few residues of TatC that are highly conserved in all domains of life (Buchanan et al., 2002) and is situated in the first cytoplasmic loop of TatC, connecting transmembrane helices II and III (Fig. 2a). Whereas substitution of the similar glutamate residue in TatCd (E96) with alanine blocks secretion of PhoD completely, TatCy $\mathrm{E}_{\mathrm{E} 102 \mathrm{~A}}$ remains active, albeit to a lesser extent when compared to wild-type secretion levels (Fig. 2b). Mutagenesis studies on this particular residue in the E. coli TatC protein have produced mixed effects on translocation activity (Holzapfel et al., 2007; Buchanan et al., 2002; Allen et al., 2002 and Supplementary Table S2). Furthermore, in spite of the absence of secretion activity, a $\mathrm{TatC}_{\mathrm{E} 103 \mathrm{~A}}$ mutant still had binding affinity for the E. coli Tat substrate Sufl (McDevitt et al., 2006). These results point to an important role of E103 in substrate translocation, which may vary depending on the type of substrate, but not in substrate binding. This may explain the differences observed between TatCy $\mathrm{E}_{\mathrm{E} 102}$ and $\mathrm{TatCd}_{\mathrm{E} 96}$, for which the secretion efficiency of two different substrates was studied.

Fig. 3(a) shows an alignment between B. subtilis TatCy, $B$. subtilis TatCd and E. coli TatC, in which the effect of amino acid substitutions in the TatC proteins on Tat substrate translocation is indicated by colours. As is clearly illustrated, amino acids that were consistently found to be essential (indicated in red) for E. coli TatC activity (R17 and E103) seem to have a different degree of importance for activity of TatCy (R19 and E102), whereas they are 
equally essential for PhoD secretion by TatCd (R16 and E96). Furthermore, as is indicated by the residues highlighted in blue, some amino acids are not essential, but show an effect on substrate binding or translocation when substituted by alanine. A comparative topological model of the $\mathrm{N}$-terminal regions of B. subtilis TatCy, TatCd and E. coli TatC is depicted in Fig. 4, in which the results of mutagenesis studies are indicated in the same colours as in Fig. 3(a). Unfortunately, no crystal structures of the TatC proteins have been elucidated yet; these could provide vital clues as to the presence of binding pockets and the positioning of individual amino acids with respect to their neighbouring residues. Therefore, the positioning of the residues in Fig. 4 is purely hypothetical, but nevertheless illustrates important differences between the three TatC proteins.

In some cases, the severity of the effects of amino acid substitutions in the TatC protein can differ depending on the substrate under study. For instance, Buchanan et al. (2002) described a complete block in transport of TorAGFP when the aspartate in position 211 in TatC was changed to an alanine or an asparagine, or a severe effect when this residue was changed to a glutamate. In contrast, the $\mathrm{TatC}_{\mathrm{D} 211 \mathrm{~A}}$ mutant was found to have no effect on secretion or binding of the Sufl substrate (Holzapfel et al., 2007; McDevitt et al., 2006). It is therefore uncertain whether differences in effects of the substituted residues in TatCy and TatCd are the result of the use of two different substrates, and if identical effects will be obtained when studying translocation of an identical substrate.

This is furthermore illustrated by reports on the effects of changes in the signal peptides of substrates under study (Mendel et al., 2008). Within the $\mathrm{N}$ region of the signal peptide, the RR motif was shown to play an essential role in binding to TatC (Alami et al., 2003). However, later reports suggest otherwise (McDevitt et al., 2006; Kreutzenbeck et al., 2007). Observations described in these studies indicate that the function of the conserved double arginine residues in Tat substrates is far more complex than simply functioning as a recognition and binding site, as was previously suggested by McDevitt et al. (2006). Equally conserved residues in the extended consensus region appear to play an important role as well. An example of these is the phenylalanine in position +2 relative to the $R R$ motif, which is highly conserved in bacterial Tat signal peptides, but almost never observed in Tat substrates of the thylakoidal Tat pathway. Interestingly, introduction of such a phenylalanine in position +2 in the tOE17 Tat substrate of thylakoids resulted in an increase of binding affinity to the TatBC (Hcf106-cpTatC) complex (Gérard \& Cline, 2007). As is shown in Fig. 3(b), all signal peptides of substrates used in the above-described mutagenesis studies contain a phenylalanine in position +2 , except for $B$. subtilis YwbN (highlighted in red in Fig. 3b). This may explain the differences in essential character of changed conserved residues between TatCy and TatCd, such as $\mathrm{TatC}_{\mathrm{E} 102}$, for the secretion of YwbN and PhoD. Additional experiments are required to prove this theory.

So far the mechanism of secretion of folded proteins by the Tat machinery remains inconclusive, although several working models for E. coli Tat have been published (reviewed by Lee et al., 2006; Sargent et al., 2006). The results from this study demonstrate that, despite Tat component similarities and regional homologies, specific differences in substrate affinity and translocation activity exist even within the same organism. Nevertheless, we agree with previous conclusions that the $\mathrm{N}$-terminal half of TatC plays a determining role in substrate translocation

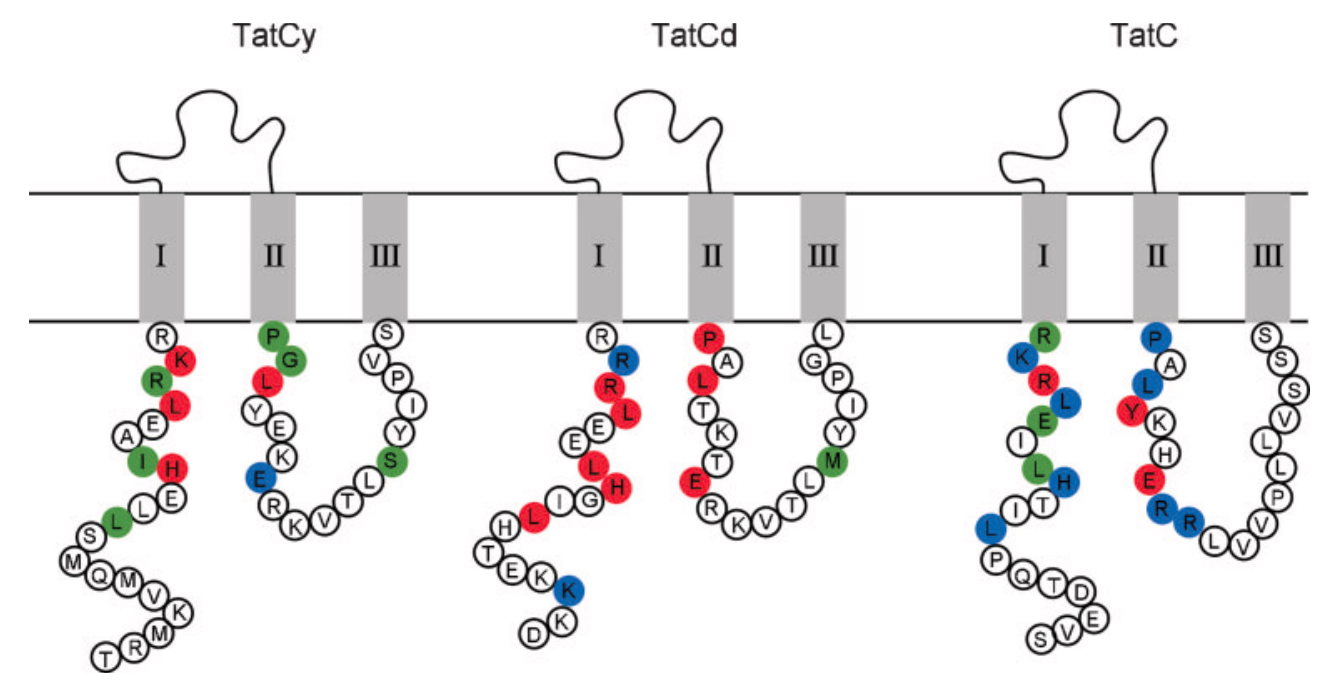

Fig. 4. Predicted topologies of the $\mathrm{N}$-terminal regions of $B$. subtilis TatCy and TatCd and E. coli TatC. The effect of amino acid substitution on residues in the cytoplasmic $\mathrm{N}$ terminus and the first cytoplasmic loop is indicated in colours: red, essential; green, non-essential; blue, important. Transmembrane domains are indicated in grey and are numbered in roman numerals. 
activity. In addition, we have shown that the extreme $\mathrm{C}$ terminus of TatCy in B. subtilis is also essential for YwbN translocation activity. We speculate that the substrate specificity determinants for Tat-dependent protein secretion in B. subtilis are a combination of explicit properties of TatA and TatC components as well as Tat substrate signal peptides and perhaps even the mature protein sequence. Together with Blue Native PAGE experiments, specific crosslinking and signal peptide mutagenesis studies, models as illustrated in Fig. 4 may provide important clues about Tat substrate binding requirements and, as a result, about Tat substrate specificity.

\section{ACKNOWLEDGEMENTS}

We would like to thank Prof. Jörg Müller for providing antibodies against B. subtilis PhoD and TatCd, and Dr Anja Ridder for critically reading the manuscript. This work was supported by PW6 grants from the European Union (LSHC-CT2004-05257).

\section{REFERENCES}

Alami, M., Lüke, I., Deitermann, S., Eisner, G., Koch, H. G., Brunner, J. \& Müller, M. (2003). Differential interactions between a twin-arginine signal peptide and its translocase in Escherichia coli. Mol Cell 12, 937946.

Allen, S. C., Barrett, C. M., Ray, N. \& Robinson, C. (2002). Essential cytoplasmic domains in the Escherichia coli TatC protein. J Biol Chem 277, 10362-10366.

Barnett, J. P., Eijlander, R. T., Kuipers, O. P. \& Robinson, C. (2008). A minimal Tat system from a gram-positive organism: a bifunctional TatA subunit participates in discrete TatAC and TatA complexes. J Biol Chem 283, 2534-2542.

Barrett, C. M., Mangels, D. \& Robinson, C. (2005). Mutations in subunits of the Escherichia coli twin-arginine translocase block function via differing effects on translocation activity or Tat complex structure. J Mol Biol 347, 453-463.

Behrendt, J., Standar, K., Lindenstrauss, U. \& Brüser, T. (2004). Topological studies on the twin-arginine translocase component TatC. FEMS Microbiol Lett 234, 303-308.

Bogsch, E. G., Sargent, F., Stanley, N. R., Berks, B. C., Robinson, C. \& Palmer, T. (1998). An essential component of a novel bacterial protein export system with homologues in plastids and mitochondria. J Biol Chem 273, 18003-18006.

Bron, S. \& Venema, G. (1972). Ultraviolet interaction and excision repair in Bacillus subtilis. I. Construction and characterization of a transformable eightfold auxotrophic strain and two ultravioletsensitive derivatives. Mutat Res 15, 1-10.

Bron, S., Bolhuis, A., Tjalsma, H., Holsappel, S., Venema, G. \& van Dijl, J. M. (1998). Protein secretion and possible roles for multiple signal peptidases for precursor processing in bacilli. J Biotechnol 64, 3-13.

Buchanan, G., de Leeuw, E., Stanley, N. R., Wexler, M., Berks, B. C., Sargent, F. \& Palmer, T. (2002). Functional complexity of the twinarginine translocase TatC component revealed by site-directed mutagenesis. Mol Microbiol 43, 1457-1470.

Cline, K. \& Mori, H. (2001). Thylakoid $\Delta \mathrm{pH}$-dependent precursor proteins bind to a cpTatC-Hcf106 complex before Tha4-dependent transport. J Cell Biol 154, 719-729.
Eder, S., Liu, W. \& Hulett, F. M. (1999). Mutational analysis of the phoD promoter in Bacillus subtilis: implications for PhoP binding and promoter activation of Pho regulon promoters. J Bacteriol 181, 20172025.

Eijlander, R. T., Jongbloed, J. D. \& Kuipers, O. P. (2009). Relaxed specificity of the Bacillus subtilis TatAdCd translocase in Tatdependent protein secretion. J Bacteriol 191, 196-202.

Gérard, F. \& Cline, K. (2006). Efficient twin arginine translocation (Tat) pathway transport of a precursor protein covalently anchored to its initial cpTatC binding site. J Biol Chem 281, 6130-6135.

Gérard, F. \& Cline, K. (2007). The thylakoid proton gradient promotes an advanced stage of signal peptide binding deep within the Tat pathway receptor complex. J Biol Chem 282, 5263-5272.

Gohlke, U., Pullan, L., McDevitt, C. A., Porcelli, I., de Leeuw, E., Palmer, T., Saibil, H. R. \& Berks, B. C. (2005). The TatA component of the twin-arginine protein transport system forms channel complexes of variable diameter. Proc Natl Acad Sci U A 102, 10482-10486.

Härtl, B., Wehrl, W., Wiegert, T., Homuth, G. \& Schumann, W. (2001). Development of a new integration site within the Bacillus subtilis chromosome and construction of compatible expression cassettes. J Bacteriol 183, 2696-2699.

Holzapfel, E., Eisner, G., Alami, M., Barrett, C. M. L., Buchanan, G., Lüke, I., Betton, J. M., Robinson, C., Palmer, T. \& other authors (2007). The entire N-terminal half of TatC is involved in twinarginine precursor binding. Biochemistry 46, 2892-2898.

Jongbloed, J. D., Martin, U., Antelmann, H., Hecker, M., Tjalsma, H., Venema, G., Bron, S., van Dijl, J. M. \& Müller, J. (2000). TatC is a specificity determinant for protein secretion via the twin-arginine translocation pathway. J Biol Chem 275, 41350-41357.

Jongbloed, J. D., Grieger, U., Antelmann, H., Hecker, M., Nijland, R., Bron, S. \& van Dijl, J. M. (2004). Two minimal Tat translocases in Bacillus. Mol Microbiol 54, 1319-1325.

Kreutzenbeck, P., Kröger, C., Lausberg, F., Blaudeck, N., Sprenger, G. A. \& Freudl, R. (2007). Escherichia coli twin-arginine (Tat) mutant translocases possessing relaxed signal peptide recognition specificities. J Biol Chem 282, 7903-7911.

Kunst, F., Ogasawara, N., Moszer, I., Albertini, A. M., Alloni, G., Azevedo, V., Bertero, M. G., Bessières, P., Bolotin, A. \& other authors (1997). The complete genome sequence of the gram-positive bacterium Bacillus subtilis. Nature 390, 249-256.

Laemmli, U. K. (1970). Cleavage of structural proteins during the assembly of the head of bacteriophage T4. Nature 227, 680-685.

Lange, C., Müller, S. D., Walther, T. H., Bürck, J. \& Ulrich, A. S. (2007). Structure analysis of the protein translocating channel TatA in membranes using a multi-construct approach. Biochim Biophys Acta 1768, 2627-2634.

Lee, P. A., Tullman-Ercek, D. \& Georgiou, G. (2006). The bacterial twin-arginine translocation pathway. Annu Rev Microbiol 60, 373395.

Mangels, D., Mathers, J., Bolhuis, A. \& Robinson, C. (2005). The core TatABC complex of the twin-arginine translocase in Escherichia coli: TatC drives assembly whereas TatA is essential for stability. J Mol Biol 345, 415-423.

McDevitt, C. A., Buchanan, G., Sargent, F., Palmer, T. \& Berks, B. C. (2006). Subunit composition and in vivo substrate-binding characteristics of Escherichia coli Tat protein complexes expressed at native levels. FEBS J 273, 5656-5668.

Mendel, S., McCarthy, A., Barnett, J. P., Eijlander, R. T., Kuipers, O. P. \& Robinson, C. (2008). The Escherichia coli TatABC system and a Bacillus subtilis TatAC-type system recognise three distinct targeting 
determinants in twin-arginine signal peptides. J Mol Biol 375, 661672.

Punginelli, C., Maldonado, B., Grahl, S., Jack, R., Alami, M., Schröder, J., Berks, B. C. \& Palmer, T. (2007). Cysteine-scanning mutagenesis and topological mapping of the Escherichia coli twin-arginine translocase TatC component. J Bacteriol 189, 5482-5494.

Sambrook, J., Fritsch, E. F. \& Maniatis, T. (1989). Molecular Cloning: a Laboratory Manual, 2nd edn. Cold Spring Harbor, NY: Cold Spring Harbor Laboratory.

Sargent, F., Bogsch, E. G., Stanley, N. R., Wexler, M., Robinson, C., Berks, B. C. \& Palmer, T. (1998). Overlapping functions of components of a bacterial Sec-independent protein export pathway. EMBO J 17, 3640-3650.

Sargent, F., Stanley, N. R., Berks, B. C. \& Palmer, T. (1999). Secindependent protein translocation in Escherichia coli. A distinct and pivotal role for the TatB protein. J Biol Chem 274, 36073-36082.

Sargent, F., Berks, B. C. \& Palmer, T. (2006). Pathfinders and trailblazers: a prokaryotic targeting system for transport of folded proteins. FEMS Microbiol Lett 254, 198-207.
Strauch, E. M. \& Georgiou, G. (2007). Escherichia coli tatC mutations that suppress defective twin-arginine transporter signal peptides. $J$ Mol Biol 374, 283-291.

Towbin, H., Staehelin, T. \& Gordon, J. (1979). Electrophoretic transfer of proteins from polyacrylamide gels to nitrocellulose sheets: procedure and some applications. Proc Natl Acad Sci U S A 76, 4350-4354.

van der Vossen, J. M. B. M., van der Lelie, D. \& Venema, G. (1987). Isolation and characterization of Streptococcus cremoris Wg2-specific promoters. Appl Environ Microbiol 53, 2452-2457.

van Dijl, J. M., de Jong, A., Venema, G. \& Bron, S. (1995). Identification of the potential active site of the signal peptidase SipS of Bacillus subtilis. Structural and functional similarities with LexAlike proteases. J Biol Chem 270, 3611-3618.

Wertman, K. F., Wyman, A. R. \& Botstein, D. (1986). Host/vector interactions which affect the viability of recombinant phage lambda clones. Gene 49, 253-262.

Edited by: F. Sargent 